\title{
From social network to firm performance
}

\section{The mediating effect of trust, selling capability and pricing capability}

\author{
Aluisius Hery Pratono \\ Faculty of Business and Economics, Universitas Surabaya, Surabaya, Indonesia
}

\begin{abstract}
Purpose - The purpose of this study is to develop a structural equation model to explain the complex relationship between social network and firm performance by introducing the mediating role of trust, selling capability and pricing capability.

Design/methodology/approach - The research model with hypothesis development was derived based on the literature. To provide empirical evidence, this study carried out a survey in which the data were equated with a list of questionnaires with a random survey of 380 small and medium enterprises (SMEs) in the Indonesian context.

Findings - This study indicates that the use of social media in management process will not affect the increasing firm performance, unless the firms build trust upon social networks. The social network with trust allows the firms to gain a pricing capability and a selling capability, which brings a positive impact on firm performance. The results also show that the selling and the pricing capabilities become essential following the utilizing the social media, which concerns on trust building.

Research limitations/implications - This study focused on the small-to-medium context, which has conventionally provided an exemplary site for the development of social capital theory but raises issues of generalizability across different contexts.

Practical implications - To the managers, it is advisable to encourage their employees to consciously exploit the selling capability by enhancing the business networks via social media to achieve the firm performance.

Originality/value - This paper contributes to the social capital theory by explaining the mediating role of trust in the complex relationship between social network and firm performance. This study provides evidence that trust plays a pivotal role in social networks, which enable the observed firms to achieve the performance.
\end{abstract}

Keywords Social network, Trust, Firm performance, Social capital theory, Entrepreneurship and small business management, Pricing capability, Selling capability

Paper type Research paper

\section{Introduction}

The social media is associated with the Internet of things that impacts the way organizations generate innovation and value in business activities (Santoro et al., 2017). The role of social media in the entrepreneurial process has been acknowledged by promoting a virtual collaborative approach for a start-up business and strategic behavior in market access (Guercini et al., 2014). Positive network externality generates competitive interaction through greater social economic value (Lado et al., 2006). Another study also supports the view that social networks have a significant impact on many aspects of firm performance (Arora et al., 2016).

The needs that drive social networks are similar in many ways to the needs to get satisfied by offline relationships (Kozienkova et al., 2017). However, nearly half of the

Received 18March 2017 Revised 20 July 2017 31 August 2017 16 October 2017 9 December 2017 Accepted 7 January 2018
From social network to firm

performance 
marketing managers believe that they are not prepared to manage the challenges of social media although they allocate resources for the social media (IBM, 2016). Harnessing the power of social networks to achieve organizational performance seems to be complicated because of some reasons. The first reason arises from over-exploitation of such relationship (Duffy et al., 2012). Second reason concerns with the overwhelmed network structures (Terpend and Ashenbaum, 2012) and the overloaded information (Schilke, 2014). Another reason argues that a different group of people has a different orientation from the use of social networking sites (Tian, 2016).

In developing economies, social media has evolved frequently (Del Giudice et al., 2013), especially when small businesses represent a major component of the economic systems (Tilmes, 2015). Despite the increased attention to the efforts of SMEs to actively exploit social networking activities, the mainstream literature still partly neglects the topics on social networks and interaction processes with regard to small business (Bocconcelli et al., 2016).

It is important to generate a greater understanding of how social capital adversely affects the performance in which the organizations have the intention to exploit social media (Oldroyd and Morris, 2012). There is a research gap in explaining the complex relationship between social network and firm performance, which becomes essential for developing a strategy theory (Afuah, 2013). This calls for a research to understand how the performance outcomes depend on mature relationships with sellers (Kozienkova et al., 2017).

To address the research gap, this article begins with a process approach to theory development to explore the role of social network structure in improving selling capability and pricing capability toward firm performance. The empirical test involved a survey on the observed variables that represent attitudes and beliefs held by small and medium enterprises (SME) in the Indonesian context. The result is expected to contribute to the development theory of social capital, which aims at understanding the role of social media in social interaction in the business context.

\section{Literature review}

Social Capital theory

The social capital theory aims to understand social ties, social interaction, trust and reciprocity, which have been used as antecedents to social media studies (Ngai et al., 2015). The seminal work of Putnam (2000) on social capital theory highlights the role of social relationship, which supports a collective action. The theory argues that a social network that gives rise to social capital provides information, influence and solidarity, which lie in the abilities of each actor of this network that can be mobilized by the goodwill (Kwon and Adler, 2014). Hence, it is essential to note that the behaviors of employees are routinized according to the aims of external organizations (Kim et al., 2012).

Social media provides opportunities to generate a reciprocal social relationship, which allows the individual in organization to build a relationship with trust, norm and network (Bjørnskov and Sønderskov, 2013). Social networks provide opportunities for both bridging and bonding social capital for seeking information (Tian, 2016). In the business context, a social network refers to the number of relationships and sharing resources (Tubadji, 2014), which allows individual achieve his expected performance (Cvtanovic et al., 2015). Knowledge absorptive capability is essential for the firms to harness the meaningful information, which springs from the customer network and the business partners (Wang and Byrd, 2017).

The concept of social capital contains social norms and networks that generate shared understandings, trust and reciprocity, which aims at enhancing a collective action for 
mutual benefits (Dinda, 2014). In this network, the individual, interpersonal and personality variables play a pivotal role in the performance of resource management (Dodd, 2016). This highlights possession of resources to maximize the benefit, which concerns with the centrality of networks that bring an existence of the author at the social structure (Marin et al., 2015). Adoption of systems to help firms go partnership with other firms with broad social capital is essential to generate value (Carayannis et al., 2017).

In building the relationship with customers, mature firms tend to have more capability to manage affluent social capital with commercial and technological information than the small firms, which allows them to gain access to valuable resources (Wang, 2016). There are two conditions related to customer-supplier relationship characteristics: a strong tie relationship with the strong perceived degree of closeness and reciprocity and customer adaptiveness that concerns on the willingness to accommodate a supplier's inquiry (Panagopoulos et al., 2017).

The social capital theory suggests that talented employees gain benefit by preserving the value of robust social capital. The talented employees may move away from managing structural redundancies in their network and begin to manage the processes by which they gain information (Oldroyd and Morris, 2012). However, there is a stream of research on the "dark side" of social capital theory, which concerns with the lack of capacity to fragment a broad collectivity in particularistic identity context (Kwon and Adler, 2014). Hence, the effective use of data interpretation tools is required to gain benefit from the open information and knowledge (Wang and Byrd, 2017).

\section{The social network and firm performance}

Social network refers to the Internet-based application that allows individuals to construct personal profiles to develop a social relationship with whom to share and interact with (Campbell et al., 2014). The concept of relational network leads to the economics network approach, which pertains to the relationships between agents that cooperate to share, acquire, and exchange resources (Del Giudice and Maggioni, 2014). The use of social media tools has also been acknowledged to encourage the customers to keep them updated on its latest products and event activities (Rathi and Given, 2017).

The collaboration becomes different as there are various modes of collaboration, including the informal inbound open innovation entry mode and the informal one (Scuotto et al., 2017). This type of network demonstrates how an actor has a close relationship in the network structure, which provides a business opportunity (Broadbridge, 2010). The social networks allow firms to attain positions of competitive advantage that persevere through time and result in sustained superior performance (Bicen and Hunt, 2012). The entrepreneur's personal network, which includes a content multiplicity of friends, business partners and relatives, provides significant support for firm growth (Kregar and Antoncic, 2016). The global database is available for professionals across the network firm, which provides a detailed information on customer behaviors, key relationships and sale management process (Foroudi et al., 2017).

The network provides opportunities for firms to reach consumers to a degree that is different from traditional advertising channels (Campbell et al., 2014). In the SME context, the adoption of social media in both in-house R\&D and an open innovation model is also relevant to achieve performance (Scuotto et al., 2017). The network structure is essential to develop the value of a product, which emerges from both consumer surplus and its network of users (Afuah, 2013). The social networks also attract followers who appreciate the brands and, therefore, pay more intention to collaborate with the firms (Cordero-Gutiérrez and Santos-Requejo, 2016).
From social network to firm performance

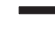


The premise is that social networks provide a social support, which helps firms to deal with uncertainty (Pinto and Araújo, 2016). Firms' central position in a network significantly improves its financial performance, which is largely mediated through its enhanced innovativeness (Dolfsma and van der Eijk, 2017). Social network with customer involvement in terms of ideating, producing or testing innovation can improve firm performance (Scuotto et al., 2017):

H1. Social network structure has a positive direct impact on firm performance.

\section{Mediating effect of trust}

The high quality of communication in social networks contributes to generating value for a new product development through communication with fans of a brand (Kucharska and Wright, 2017). However, network ties do not always have a direct impact on work performance because the influence is partially mediated by other variables (Cao et al., 2016). Trust is essential to promote adaptive organizational forms, such as building social network relations and reduce harmful conflict (Salam, 2017).

Through long-term interactions, relationships evolve built on mutual adaptation, commitment and trust (Chen et al., 2013). The network engagement fills the gap in trust between firms and their stakeholders, which relies on reducing the cost of experiential learning for firms (Gao et al., 2016). Trust building is a fundamental element for firms, suppliers and distributors to understand each other, which entails the reconfiguration process to allow the firm acquirers nurture the core competencies and expertise (Shin $e t$ al., 2017).

Social media can promote the formation of employees' social capital indicated by network ties, shared vision and trust (Cao et al., 2016). Trust has important implications for economies, as it facilitates the transactions that take place between the members of society. Countries with a high level of trust decrease monitoring cost and hence are able to attract investment opportunities (Niazi and Hassan, 2016). Trust among stakeholders improve a quality of networks as they validate their role by a collaboration, which relies on operational performance. This encourages firms to invest more resources to support collaboration and integration across stakeholders (Salam, 2017):

H2. Trust positively mediates the relationship between social network structure and firm performance.

Selling performance requires the capability of firms to build consumer trust, which encourages direct selling companies to devote more time to promote how trustworthy they and the individual salespersons are (Poon et al., 2017). Selling capability is associated with the capability of firms to develop a strong network relationship to promote motivation of the exchange parties to share resources and information and thus contributes to the sales performance (Wu et al., 2016).

Firms that tie social network with customers will be able to develop trust in the online marketplace, while those who are less familiar with the social networks tend to be less trusting in online marketing (Campbell and Fairhurst, 2016). Trust is essential for firms to assess the relationship and the strength of the bond in a timely manner and, therefore, depends on a strong customer relationship (Akrout et al., 2016).

For a salesperson, the form of trust involves interpersonal trust with customers, intraorganizational trust with the firms and inter-organizational trust between the firms and other organizations. Among them, the interpersonal trust is expected to have the strongest influence on the direct selling industry (Poon et al., 2017). The developed relationship relies 
on enhancing mutual dependence and relational governance through norms, while the relationship with the low level of development calls for trust and commitment (Zhang et al., 2016):

H3. Trust positively mediates the relationship between social network structure and selling capability.

Social network development allows consumers to regularly visit an online marketplace and build trust, which becomes attune to the pricing structure, which depends on shopping behavior no matter what the cost (Campbell and Fairhurst, 2016). The pricing capability is part of marketing capability, which is essential for the firms to achieve the performance (Pratono and Mahmood, 2015). The combination of such resources influences the price capability and substitute the effect of brand names on their prices (Qiu and Leszczyc, 2016).

To accomplish the firms' purposes, they need to move beyond informational support and develop the capability to adjust and transfer knowledge which requires further interpersonal bonds and trust (Pinto and Araújo, 2016). Firms that succeed to gain customers' trust tend to develop adaptively and selling oriented approach to anticipate misinterpretation of their customers' behavior (Guenzi et al., 2016).

When an online pricing error is involved, consumers may perceive that compensation in the form of price reduction (Lii and Lee, 2012). However, consumers may accept the potentially higher prices that local food commands and may allow some other suppliers with more flexibility to increase category prices for local items without sacrificing possible product "switching" by customers to similar non-local items (Campbell and Fairhurst, 2016). As a critical antecedent, the trust may lead to an unmanaged, untrained and uninformed relationship, especially when the agent fails to manage the emotions and dynamics of the interaction (Jarvenpaa and Majchrzak, 2016):

H4. Trust positively mediates the relationship between social network structure and pricing capability.

\section{Mediating effect of selling capability}

Selling capability refers to the extent to which firms can manage selling a wide range of products to the existing customers (Brush et al., 2012), which allows the firms to develop strong relationships with the customer and target the potential customer effectively (Borg and Johnston, 2013). Selling products locally needs networks, which may entail distribution agent that can offer coverage of chosen markets (Kamboj and Rahman, 2015). Firms that increasingly rely on the external sources of suppliers and partners have more opportunities to achieve a better innovative performance (Ferraris et al., 2017).

Social capital has been acknowledged as one of the main determinants of selling capability and may evoke the communication network between selling center members and the selling center's connections with the customer's buying center (Yang et al., 2011). The level of trust increases selling capability and finally affects the customers' preference (Hartmann and Caerteling, 2010). Selling products require network structure, which may involve distribution agent that can offer coverage of chosen markets (Kamboj and Rahman, 2015).

Most firms spend their resources to focus on the selling capability to seize business opportunities and achieve the performance (Bundy et al., 2013). To gain value-based selling capability, firms are required to narrow the gap between value creation in selling and sales management (Jaakkola, Frösen, and Tikkanen, 2015). The increase in the depth of seller competition increases platform revenue in the short term, but it intensifies sellers' mutual
From social network to firm performance 
containment, which will influence the sustainable and healthy development of platforms negatively in the long term (Li et al., 2015).

On the other hand, transforming the dense network to performance becomes less effective than when transitioning from other types of ties and structures. It needs support from expertise for making the relationship more viable (Perry-Smith and Mannucci, 2017). As the level of social network differs in which the offline relational partners typically have more common friends than social networks, there is an increased risk that an online partner might behave opportunistically (Kozienkova et al., 2017):

H5. Selling capability positively mediates the relationship between social network structure and firm performance.

Pricing capability relies on selling performance, which can be biased when markets are spread over different areas. Under high market uncertainty, the option to change the network configuration is essential for firm performance (Fernandes et al., 2015). On the other hand, the advantageous network influences the price fairness that a customer has more opportunities to purchase the identical product with a lower price than others, which leads to the higher intention to purchase it (Lee et al., 2011). The decline of the social network occurs when betrayal undermines social capital due to direct negative attribution to the selling capability (Zhang et al., 2016).

Customers will feel empowered to demand when suppliers enhance their future outcomes through strengthening their relationship with customers (Wetzel et al., 2014). Building a close relationship with competitors allows firms to stay proactive and develop the networks, which relies on a set of core capabilities to deal with their interdependencies (Xu et al., 2016). In a business organization, the sales force demonstrates its capabilities to deliver the sales targets by adapting to the demand in a way that serves as a foundation for long-term profitable relationships (Singh et al., 2017).

The reputation of employees with the social network becomes a signal for sellers' reliable and trustworthy, which depends on the buyer's likelihood to form a social network as relational observation of the seller increases (Kozienkova et al., 2017). This requires a fundamental change-management process that evokes trustworthy to encourage an organizational culture with novel experiments and ideas (Liozu and Hinterhuber, 2013);

H6. Selling capability positively mediates the relationship between social network structure and pricing capability.

The social network may have a stable unilateral structure, where a relationship partner never reciprocates but remains in the unilateral relationship as a follower, which does not occur with offline relationships owing to the social barrier to reciprocate (Kozienkova et al., 2017). Hence, consumers tend to be more prone to buy trusted brands, while the distributors become more confident in selling trusted brands (Konuk, 2015).

In a high-pressure business environment, a salesperson may be tempted to use hard selling approaches, which may undermine a company's ability to build long-lasting relationships with its customers based on trust (Guenzi et al., 2016). Firms with premium price need to be economically viable to fully maintain trust and pricing capability in the social relationship context (Kluge and Fassnacht, 2015).

For firms, which rely on online retail, pricing capability determines the firm performance, especially as retailers can lower the likelihood of returns by increasing the proportion of sales made under the price leadership condition (Ishfaq et al., 2016). However, as the social network has been acknowledged as drivers for pricing capability, there are some reasons 
that change the positive impact on firm performance, such as a bad core at the social network (Perry-Smith and Mannucci, 2017):

H7. Selling capability positively mediates the relationship between trust and pricing capability.
From social network to firm performance

\section{Mediating effect of pricing capability}

Pricing capability demonstrates the capability of firms to set a price that reflects the value of its customers (Duta et al., 2003). Firm capability to manage the channel partners is essential for further improvement of organizational marketing capabilities (Tang et al., 2017). This induces the capability to deal with decreasing consumer's motivation regarding the low price strategy (Aydinli et al., 2014).

Becoming a best seller is also driven by the reputation of the firm, which has invested the number of resources for social networks and advertising (Kocas et al., 2018). Hence, developing the pricing capability is associated with developing organizational change capacity (Liozu and Hinterhuber, 2013). This requires a consistent value of the products that consumers perceived, which relies on various sources, such as service distinctive features, service attitude to meet customers' needs and effectiveness of communication strategies about the service value (Calabrese and De Francesco, 2014).

The pricing capability needs to deal with optimal pricing problem, which springs from suppliers, especially when failure rate increases due to the cumulative demand functions (Chen et al., 2017). That value-based pricing leads to superior performance is very much possible that the costs of the required changes at the actor, activity and resource level exceed the benefits (Liozu and Hinterhuber, 2013). This involves the portfolio of value creation and value appropriation capabilities to create competitive advantages (Duta et al., 2003).

This capability relies on network structures, which provide information quality. This induces the integrated promotion, which includes integrated pricing information that generates reliability in product images and prices through a market channel (Foroudi et al., 2017). Capability to deal with the social network is essential to recover quickly from environment turbulence (Chowdhury and Quaddus, 2017). This capability to adapt the dynamic environment plays a central role in pricing and leads to enhance their performance (Hofer et al., 2015). To reduce the problem of random matching, the online sellers can choose between the strategies of auction only or (ii) auction with a buy-it-now option, which involves social network structure (Anwar and Zheng, 2015):

H8. Pricing capability positively mediates the relationship between social network structure and firm performance.

Firm capability to deal with network structure is essential to deal with various levels of conflict, which encompasses the capability to leverage their mutual knowledge (Tang et al., 2017). This relies on the quality of network structure because of cost-informed and valueinformed pricing, which figure out the implementing strategies (Ingenbleek and van ders Lans, 2013). Consumers' perception of the process of price setting is a crucial factor that leads to perceived price fairness (Lee et al., 2011). Typically, main customers do not compromise on price, unless there is trust between customers and suppliers (Hartmann and Caerteling, 2010).

The pricing strategy is a complex system, which needs to deal with information constraints and goal conflicts. For example, a lack of credible information leads to a conflict between sales and revenue managers (van der Rest et al., 2018). Firms may rely on an external network structure to conduct pricing flexibility by setting the price according to 
information, which is readily under the control of the firm (Marricano, 2014). Most of the sale efforts do not evolve much on the social network, while some of them go beyond the social network to become a competing seller. The selling capability increases the product value, which raises the level of independence on price and brand (Holden, 2016):

H9. Pricing capability positively mediates the relationship between trust and firm performance.

Firms with selling capability recognize that many products are able to generate some degree of cross-selling opportunity (Kocas et al., 2018). Traditional approaches for managing prices face challenging issues from a complex environment. This depends on varied pricing performance among firms, while channel conflicts lead to profit losses (Carriano, 2014). There are some trends regarding the intangible benefits that were not considered and could benefit the overall value of the work (Kamboj and Rahman, 2015). Lower price under price leadership results in higher product returns and become a signal of lower quality and results in a negative ex-post evaluation of products (Ishfaq et al., 2016).

Typically, firms use quite simple procedures to set their prices instead of other complex methods (Carriano, 2014). On the other hand, main buyers select products or services that have a lower price than alternative bids (Hartmann and Caerteling, 2010). Under high price competition, fairness perception is essential for sellers, who may experience less unfair payoff distribution (Bartling et al., 2017). There is still potential in developing further pricing capability where a pricing scheme reflecting the interdependencies when it comes to the market clearing (Briskorn et al., 2016):

H10. Pricing capability positively mediates the relationship between selling capability and firm performance.

\section{Methods}

To examine the complex relationship between network structure and firm performance, this study developed a structural equation model based on the previous literature. The research model involves five latent variables, which were adapted from literatures, i.e. firm performance (Schilke, 2014), network structure (Parra-Requena et al., 2012), trust (Rouziés and Hulland, 2014), selling capability (Morgan et al., 2009), selling and pricing capability (Morgan et al., 2009). There are 26 items of measures with seven Likert scales, which represent five constructs (see Table I).

The empirical research pertains to analyzing sample survey that was conducted in Indonesia between 2014 and 2015. A random sample selection was derived from the database of registered firms provided by the Department of Trade and Industry, the Government of Indonesia. The survey hired a professional call center that contacted the 1,000 initial firms and the final result involved 380 usable responses that provided information on all constructs.

To test the hypothesis, this study used partial least square method to examine the proposed structural equation model. Smart PLS 2.0 was used to estimate complex causeeffect relationship models with latent variables. This method is relevant to theory development in exploratory research, which involves reliability test, including composite reliability, and the average variance extracted. This software also provides outer loading analysis to make sure that the model has an acceptable quality. The path analysis was used to examine the relationship between social networks, firm performance and the mediating effect of the observed variables. 


\begin{tabular}{|c|c|c|c|}
\hline Latent variables & Items & Description & From social \\
\hline \multirow[t]{7}{*}{ Firm performance } & FP01 & Sales growth performance during the last three years & \\
\hline & FP02 & Sales growth relative to direct competitors & \\
\hline & FP04 & Gross profit in the last three years & pertormanc \\
\hline & FP05 & Return on asset & \\
\hline & FP06 & Return on investment & \\
\hline & FP07 & Return on sales & \\
\hline & FP08 & Overall performance in the last three years & \\
\hline \multirow[t]{4}{*}{ Social networks } & SN01 & We usually relate our firm's partners through social media & \\
\hline & SN02 & $\begin{array}{l}\text { We maintain close social relationship with our firm's partners through } \\
\text { social media }\end{array}$ & \\
\hline & SN03 & $\begin{array}{l}\text { The exchanges of information among our firm's partners in social media } \\
\text { have a similar content }\end{array}$ & \\
\hline & SN04 & $\begin{array}{l}\text { Our partners from which we receive advice and information for making } \\
\text { decision is connected each other in social media }\end{array}$ & \\
\hline \multirow[t]{5}{*}{ Pricing capability } & $\mathrm{PC} 01$ & We respond competitors' pricing tactic & \\
\hline & $\mathrm{PC} 02$ & We have public communication skill & \\
\hline & $\mathrm{PC} 04$ & We inform the cost structure to our customers & \\
\hline & $\mathrm{PC} 05$ & Setting competitive price is our concern & \\
\hline & PC06 & Our new products were successful & \\
\hline \multirow[t]{5}{*}{ Selling capability } & $\mathrm{SC} 01$ & Our firm provides salesperson the training that they need to be effective & \\
\hline & $\mathrm{SC} 02$ & Our firm sets sales management planning and control system & \\
\hline & $\mathrm{SC} 03$ & Our firm has skillful salesperson & \\
\hline & $\mathrm{SC} 04$ & Our firm develops sales management skills & \\
\hline & $\mathrm{SC} 05$ & Our firm provides effective sales support to the sales force & \\
\hline \multirow[t]{4}{*}{ Trust } & TR02 & We are always honest to our partners & \\
\hline & TR06 & Sales trust us to do the right thing & \\
\hline & TR07 & We always act in the spirit of cooperation & Table I. \\
\hline & TR08 & A healthy "give and take" relationship exists between our firm and partners & Measures \\
\hline
\end{tabular}

The mediating test is expected to identify whether the relationship between the social networks requires the mediating variables. Partial mediation occurs. All other situations under the condition, both direct and indirect effects, are significant to represent partial mediation, while a full mediation occurs if the effect of the social networks to firm performance is completely transmitted with the help of other variables. In this way, it can completely pass or hinder an effect in terms of another effect (Nitzl et al., 2016).

\section{Findings}

Table II shows the profile of the observed firms that vary at the social network structure level. For those who have survived for less than five years, the social network structure was considered to be great for 83 firms or 37 per cent respondents. Similarly, firms that have survived for 5-25 years have a better social network structure. But this was different in the case of firms more than 25 years old. From asset ownership, 242 respondents or 62 per cent of the observed firms are considered to be medium enterprises with assets greater than IDR500 million. Among these firms, 36 respondents acknowledged that their social network structures experienced greater than moderate level.

Prior to hypothesis testing, it is necessary to make ensure the validity and reliability of the observed variables. Table III shows that the latent variables have Cronbach's alpha coefficients greater than 0.8 . This indicates that a set of items for each latent variable has a high internal consistency. The composite reliability returned around 8 and 9.5, which also 


\section{MRR}

\begin{tabular}{lrrrrrrr}
\hline Social network structure & 1 & 2 & 3 & 4 & 5 & 6 & 7 \\
\hline Firm age & & & & & & & \\
Less than 5 years & 19 & 28 & 30 & 64 & 42 & 40 & 1 \\
Between 5 and 10 years & 4 & 14 & 9 & 17 & 16 & 8 & 3 \\
Between 10 and 25 years & 7 & 13 & 7 & 16 & 18 & 7 & 1 \\
Between 25 and 50 years & 3 & 1 & 3 & 3 & 4 & 1 & 0 \\
More than 50 years & 0 & 0 & 0 & 1 & 0 & 0 & 0 \\
Firm assets & & & & & & & \\
Less than IDR50 million & 3 & 4 & 3 & 4 & 8 & 5 & 1 \\
Between IDR50 and IDR500 million & 10 & 18 & 16 & 32 & 20 & 17 & 2 \\
Between IDR500 million and IDR10 billion & 20 & 34 & 30 & 65 & 52 & 34 & 2 \\
Firm annual sales & & & & & & & \\
Less than IDR300 million & 7 & 12 & 12 & 17 & 14 & 13 & 1 \\
Between IDR300 million and IDR2.5 billion & 23 & 36 & 34 & 67 & 52 & 38 & 2 \\
Between IDR2.5 and IDR50 billion & 3 & 8 & 3 & 17 & 14 & 5 & 2 \\
\hline
\end{tabular}

\section{Table II.}

Profile of

respondents based on a social network level

\section{Firm annual sales}

Between IDR300 million and IDR2.5 billion

\begin{tabular}{llcccr}
\hline & \multicolumn{5}{c}{} \\
\cline { 2 - 6 } & Latent variables & Cronbach's alpha & rho_A & Composite reliability & AVE \\
\cline { 2 - 5 } & Firm performance & 0.912 & 0.917 & 0.930 & 0.654 \\
Table III. & Social network & 0.801 & 0.814 & 0.870 & 0.626 \\
Construct reliability & Trust & 0.934 & 0.937 & 0.950 & 0.790 \\
and validity & Pricing capability & 0.934 & 0.937 & 0.950 & 0.790 \\
& & 0.842 & 0.859 & 0.885 & 0.609 \\
\hline
\end{tabular}

indicates that the observed latent variables are internally consistent. Regarding the convergent validity, the average variance extracted shows that that the validity of the constructs and the individual variables are greater than 0.85 , while rho measures are greater than 0.8 . Overall, the result shows that the constructs have a high validity and reliability. The outer-loading values are greater than 0.7 , which indicates that selected items represent the contribution of the indicators to the latent variable (see the Appendix).

The standardized root-mean-square residual (SRMR) based on transforming both sample covariance matrix and predicted covariance matrix into correlation matrices. A value less than 0.08 is considered a good fit (Hu and Bentler, 1998). The SRMR is a goodness-of-fit measure for PLS-SEM that can be used to avoid model misspecification (Henseler et al., 2013).

The d_LS (i.e. the squared Euclidean distance) and d_G (i.e. the geodesic distance) represent two different ways to compute this discrepancy (Dijkstra and Henseler, 2015). Hence, the result shows that the model fits well as the differences between the correlation matrix and the empirical correlation matrix are non-significant $(p>0.05)$.

The normed fit index (NFI) is defined as 1 minus the $\mathrm{Chi}^{2}$ value of the proposed model divided by the $\mathrm{Chi}^{2}$ values of the null model. The result shows that NFI is 0.765 , which indicates that the model is not quite fit as the NFI values above 0.9 usually represent acceptable fit (Table IV).

Table V provides bootstrap results that not all path coefficients are significant, while Figure 1 shows the path coefficients of each latent variables by algorithm approach. Table $\mathrm{V}$ shows that $H 1$ is not accepted. This indicates that there is no direct effect of network structure on firm performance. This result confirms the previous literature that networking 
is not sufficient resource, which was expected to bring firm with expected performance $(\mathrm{Xu}$ et al., 2016).

The result shows that $H 2$ is acceptable as the $t$-values of social network on trust is 8.571 and $t$-values of trust on firm performance is 4.298. This indicates that trust provides full mediation effect on the relationship between the social network and firm performance. This validates the previous study that states that trust improves the quality of networks, which relies on firm performance and encouraging firms to invest more resources (Salam, 2017).

$H 3$ is accepted, which indicates that trust mediates the relationship between social network and selling capability. Network structure has a significant impact on trust with $t$-values at 8.571 and trust has a significant impact on selling capability with $t$-values at 7.269. This result is consistent with the previous studies, which highlight that a firm that can build customers trust from their networks will be able to encourage their selling partners to devote more time to promote how trustworthy (Poon et al., 2017).

$H 4$ is acceptable as trust mediates the relationship between network structure and pricing capability. The impact of network structure on trust is significant with $t$-values at 8.571, while the positive impact of trust on selling capability is also significant with $t$-values at 7.269. This result is consistent with the previous studies, which mention that trust is found to be essential to help firms accomplish their purposes (Pinto and Araújo, 2016) by developing adaptively and selling capability (Guenzi et al., 2016).

$H 5$ is accepted, which indicates that selling capability provides a full mediating effect on the relationship between network structure and firm performance. The bootstrap provided a result that network structure has a significant impact on the selling capability with $t$-values at 4.790 and selling capability has a significant impact on firm performance with $t$-values at 3.899. That provides consistent evidence that communication networks between selling center members and firms contribute to selling capability (Yang et al., 2011).

\begin{tabular}{|c|c|c|c|}
\hline Model-fit measurement & Saturated model & Estimated model & \\
\hline SRMR & 0.007 & 0.07 & \\
\hline d_ULS & 2.292 & 2.292 & \\
\hline d_G & 1.578 & 1.578 & \\
\hline Chi-square & $2,351.49$ & $2,351.49$ & Table IV. \\
\hline NFI & 0.765 & 0.765 & Goodness of fit \\
\hline
\end{tabular}

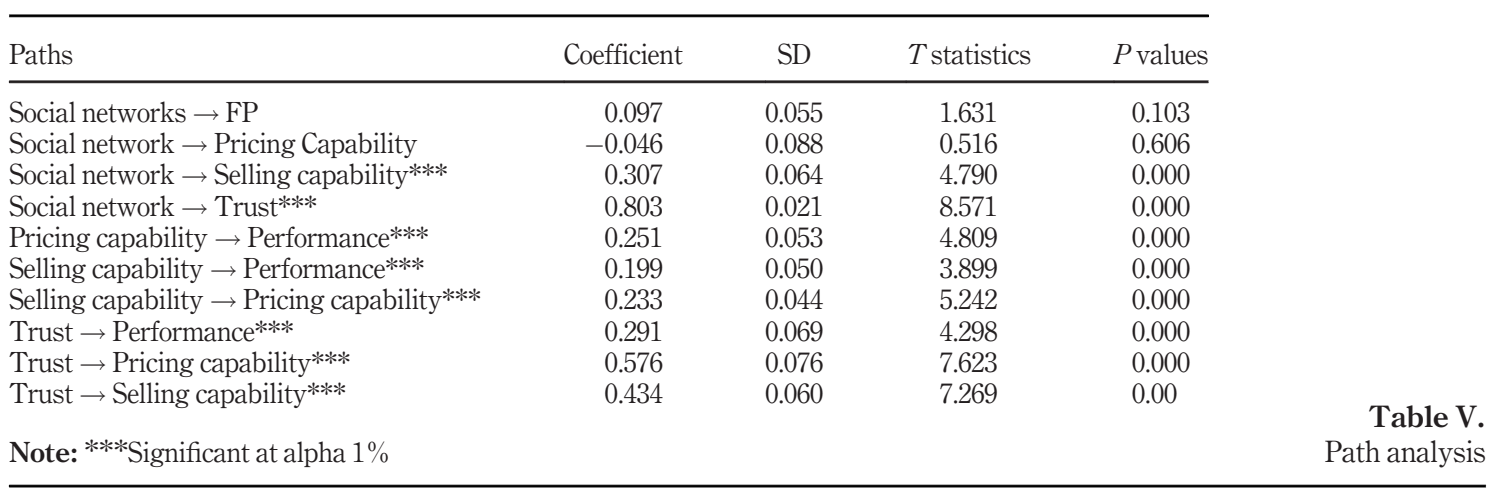

From social network to firm performance 
MRR

Figure 1.

Path analysis

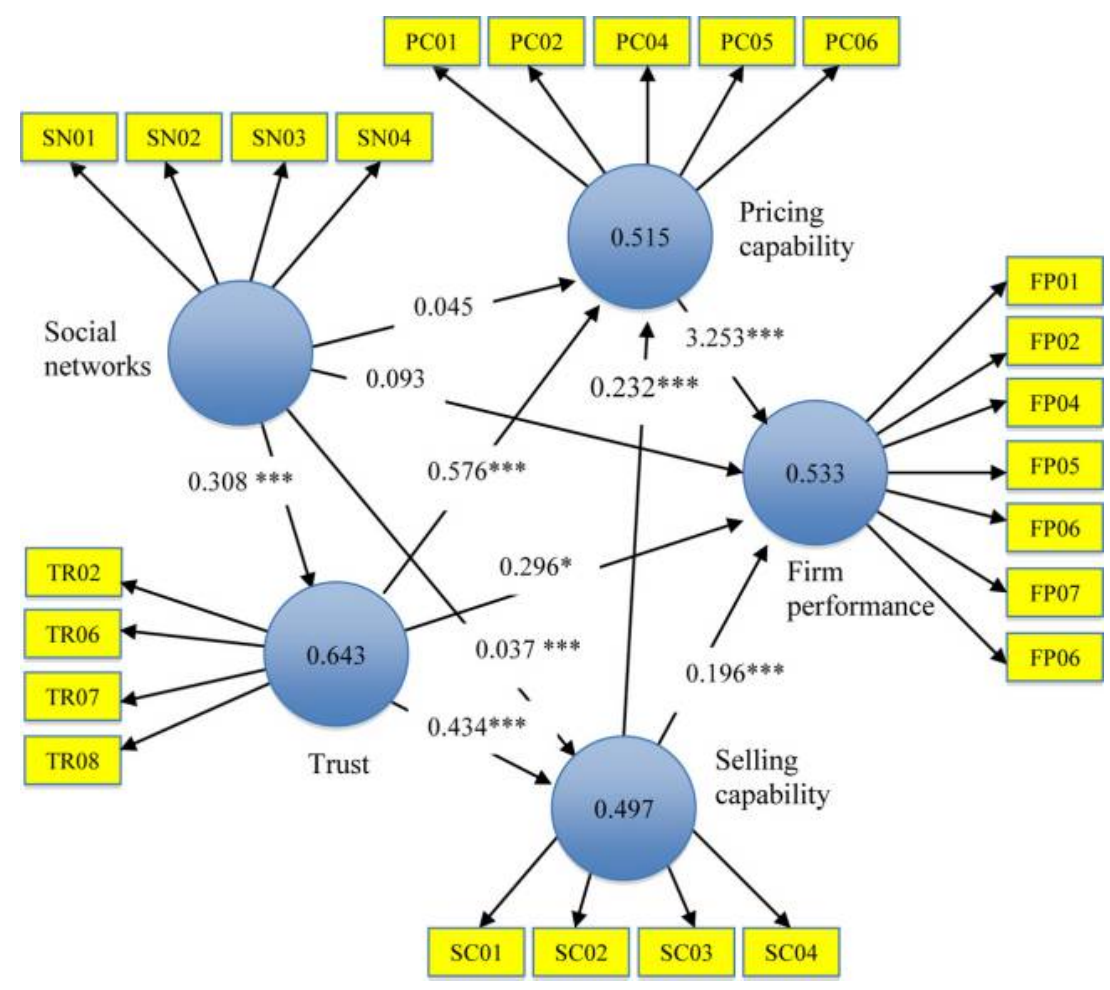

H6 has accepted that selling capability mediates the relationship between network structure and pricing capability. Network structure has a significant impact on the selling capability with t-values at 4.790, and selling capability has a significant impact on the pricing capability with t-values at 5.242. This result shows a consistency with the previous study that advantageous network influences the price competitiveness.

$H 7$ is accepted that the mediating effect of selling capability in the relationship between trust and pricing capability. Trust has a significant impact on selling capability and pricing capability has a significant impact on pricing capability with t-values 7.269 and 5.242 , respectively. This result gains support from the previous study that consumers' trust allows the firms to become more confident in selling their products, which implies on pricing capability (Konuk, 2015). To fully maintain pricing capability in the social relationship context, firms need to be economically viable (Kluge and Fassnacht, 2015).

$H 8$ is not acceptable as the impact of network structure on pricing capability is not significant as $t$-values was 0.516 , although pricing capability has a significant impact on firm performance with $t$-values at 4.809 . This result gains support from some previous studies, which argues that networks do not always provide a positive impact on firm performance because of various levels of institutional maturity or spillover effect (Kwon and Adler, 2014).

H9: Pricing capability mediates the relationship between trust and firm performance. Trust has a significant impact on pricing capability with t-values at 7.623 and pricing capability has a significant impact on firm performance with t-values at 4.809 . This result is 
in line with the previous studies, which argue that customers do not compromise on price unless there is trust between customers and suppliers (Hartmann and Caerteling, 2010) or the quality of network structure determines the pricing capability through cost-informed and value-informed strategy (Ingenbleek and van ders Lans, 2013).

H10: Pricing capability mediates the relationship between selling capability and firm performance. Selling capability has a significant impact on pricing capability and pricing capability has a significant impact on firm performance. This result confirms the previous study, which argues that selling capability demonstrates the firms' capabilities for longterm profitable relationships (Singh et al., 2017). The selling capability increases the product value, which relies on a high level of price capability (Holden, 2016) that becomes a signal for a reputation social network (Kozienkova et al., 2017).

\section{Implication for theory and practices}

This study confirms the previous studies, which argue that social networks provide support to the firm performance (Bicen and Hunt, 2012; Kregar and Antoncic, 2016; Foroudi et al., 2017). Hence, this study highlights trust, which plays a pivotal role in the social network structure that allows the observed firms to generate selling capability and pricing capability, which in turn provide a positive impact on firm performance. This provides evidence that firms can exploit social media to enhance their pricing capability. The study also shows that the social network has no direct impact on firm performance. This indicates that the initiative to exploit social networks is not sufficient to generate profit, unless it entails the trust-based relationship that plays a pivotal role to deal with the complex relationship between social network and firm performance.

\section{Theoretical implication}

The result contributes to extending the discussion on the social capital theory as below. First, this study extends the previous studies concerning the social network theory that gives rise to social capital, which has been used as antecedents to social media studies (Ngai et al., 2015) and requires an explanation on the mediating effect by other variable (Cao et al., 2016). This begins with a process approach to theory development to explore the role of social network structure in improving selling capability and pricing capability toward firm performance. The result extends the previous works on the appalling condition, which determines the customer-supplier relationship characteristics (Panagopoulos et al., 2017).

Second, this result provides an explanation to the research gap, which raises a question on how the performance outcomes depend on relationship relationships and payoffs to sellers, as stated by previous studies (Kozienkova et al., 2017). Once firms gain pricing capability and greatest firm performance, the trust-based network effect may generate competitiveness. This highlights a strong tie relationship with a strong perceived degree of closeness and reciprocity that concerns with the willingness to accommodate a supplier's inquiry.

Third, this study extends the discussion of the previous study about the capability of SMEs in managing affluent social capital with social media (Wang, 2016). Firms with the capability to develop trust-based social networks will be able to achieve the expected performance through enhanced selling and pricing capability. This confirms that the previous study, which argues that adoption of systems that help the firms to establish alliances with broad social capital leads to the value growth creation (Carayannis et al., 2017).
From social network to firm performance

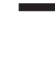


This study suggests that firms and policymakers need to pay close attention to the social positions of their employees who engage social networks wherein the social media helps firms to build a good relationship with their customers. Employees must engage not only in correspondence with their business partners and customers but also increasingly with their own firms. Firms are encouraged to enhance their selling capability, which concerns with transcending the customer-facing role and becoming a change agent for their firms as well.

Social networks with trust enable firms to gain pricing capability, which demonstrates high bargaining position with customers and depends on high firm performance. Hence, the firms need to develop a mechanism to ensure that their sales people become more confident to deal with asymmetric information, such as misrepresenting products and outright fraud. Firms often mistakenly expect that they need to gain benefit from social networks as quickly as possible but neglect the social capital, which depends on carrying an element of risk. To gain advantage from social media, firms should pay greater intention to build trust when managing their social networks.

Second, firms should improve their selling capability through enhancing social networks with trust, which will have an outsized impact on pricing capability - a proven route to the firm performance. Firms are encouraging to gain a deeper understanding of its current price position relative to consumers' perceptions. This will reveal actual price gaps wherein social networks allow salespeople to ask consumers how to select a product, and gauging how they view each provider's pricing on the relevant products. Strengthening social networks allows firms to understand how consumers perceive the firm performance.

Given the importance of selling capabilities, businesses need to concern on recruitment system into sales roles, and in-service training for their salespeople. Relational skills and selling capabilities include the ability to manage multi-level, multi-functional social networks as well as the ability to understand relational dynamics and inspire trust. Rather than focusing on product features in the sales meeting, firms should encourage the salespeople to listen and respond their networks. They should be flexible and think in terms of developing a solution to an emerging customer problem.

Third, rather than tapping into a great number of targeted markets of social networks, firms are encouraged to carefully examine what they want to accomplish through social networks. Identifying the pattern and level of connectivity will be relevant to help them to build mutual trust and respect with customers. Involving the financial consequences of prioritized relationship investments might fruitfully consider the role of customer entitlement and its underlying rank equilibrium norm.

Although trust and commitment tend to move in unison, divergent levels of relational norms and dependence are important for state identification (Zhang et al., 2016). As the level of social network differs in which the offline relational partners typically have more common friends than social networks, there is an increased risk that an online partner might behave opportunistically, thus enhancing the importance of trust-building signals during the relationship formation process (Kozienkova et al., 2017).

\section{Limitation and future research direction}

To derive the argument presented above, this study made a few simplifying assumptions. To meet the principles of parsimony, the proposed model concerns selected variables and other exogenous variables were neglected. Future studies are encouraged to examine another moderating variable, such as information technological turbulence.

Future studies should consider multiple facets of a customer relationship, because what may appear to be one type of relationship actually may be another, and the identification can 
have important implications for appropriate managerial action. For example, different patterns of all four state variables determine unique state conceptualizations. The challenges of managing growing social networks, building trust and achieving greater pricing capability and performance may need to deeply understand the needs of customers, regulators and society in shaping the future.

This study focused on the small-medium enterprises, which has historically provided an exemplary site for the development of social capital theory (Cvtanovic et al., 2015; Bocconcelli et al., 2016; Gao et al., 2016; Pratono, 2016) but raises issues of generalizability across different contexts. The insights of this study may be particularly relevant to other types of organization and fields in which significant power differentials exist between actors.

\section{Conclusion}

This study indicates a positive relationship between social networks and firm performance. This entails trust as a strong mediating variable, which provides an explanation about the essential process of transforming social networks to firm performance. Hence, the social network with trust will help the firms gain benefits from the pricing and selling capability, which in turn allow them to achieve the performance. The results highlight a critical factor of social network on firm performance, which contributes to the social capital theory in the social media context.

\section{References}

Afuah, A. (2013), "Are network effects really all about size? The role of structure and conduct", Strategic Management Iournal, Vol. 34 No. 3, pp. 257-273.

Akrout, H., Diallo, M.F., Akrout, W. and Chandon, J.-L. (2016), "Affective trust in buyer-seller relationships: a two-dimensional scale", Iournal of Business \& Industrial Marketing, Vol. 31 No. 2, pp. 260-273.

Anwar, S. and Zheng, M. (2015), "Posted price selling and online auctions", Games and Economic Behavior, Vol. 90, pp. 81-92.

Arora, A., Gittelman, M., Kaplan, S., Lynch, J., Mitchell, W. and Siggelkow, N. (2016), “Question-based innovation in strategy research methods", Strategic Management Iournal, Vol. 37, pp. 3-9.

Aydinli, A., Bertini, M. and Lambrecht, A. (2014), "Price promotion for emotional impact", $\underline{\text { Lournal of }}$ Marketing, Vol. 78 No. 7, pp. 80-96.

Bartling, B., Grieder, M. and Zehnder, C. (2017), "Competitive pricing reduces wasteful counterproductive behaviors", Lournal of Public Economics, Vol. 156, pp. 34-47.

Bicen, P. and Hunt, S.D. (2012), "Alliance market orientation, new product development, and resource advantage theory”, Iournal of Business \& Industrial Marketing, Vol. 27 No. 7, pp. 592-600.

Bjørnskov, C. and Sønderskov, K. (2013), "Is social Capital good?", Social Indicator Research, Vol. 114 No. 3, pp. 1225-1242.

Bocconcelli, R., Cioppi, M., Fortezza, F., Francioni, B., Pagano, A., Savelli, E. and Splendiani, S. (2016), "SMEs and marketing: a systematic literature review", International Journal of Management Reviews, Vol. 18 No. 4.

Borg, S. and Johnston, W. (2013), "The IPS-EQ model: interpersonal skills and emotional intelligence in sales process", Lournal of Personal Selling and Sales Management, Vol. 33, pp. 39-51.

Briskorn, D., Jørnsten, K. and Zeise, P. (2016), "A pricing scheme for combinatorial auctions based on bundle sizes", Computer \& Operations Research, Vol. 70, pp. 9-17.

Broadbridge, A. (2010), "Social Capital, gender and careers: evidence from retail senior managers", Equalitv. Diversitv and Inclusion: An International Iournal, Vol. 29 No. 8, pp. 815-834. 
Brush, T., Dangol, R. and O'Brien, J. (2012), “Customer capabilities, switching costs, and bank performance", Strategic Management Journal, Vol. 33, pp. 1499-1515.

Bundy, J., Shropshire, C. and Buchholtz, A. (2013), "Strategic cognition and issue salience: toward an explanation of firm responsiveness to stakeholder concerns", Academy of Management Review, Vol. 38 No. 3, pp. 352-376.

Calabrese, A. and De Francesco, F. (2014), "A pricing approach for service companies: service blueprint as a tool of demand-based pricing”, Business Process Management Journal, Vol. 20 No. 6, pp. 906-921.

Campbell, J.M. and Fairhurst, A.E. (2016), "Reducing the intention-to-behaviour gap for locally produced foods purchasing: the role of store, trust, and price", International Iournal of Retail \& Distribution Management, Vol. 44 No. 5, pp. 508-523.

Campbell, C., Ferraro, C. and Sands, S. (2014), "Segmenting consumer reactions to social network marketing”, European Journal of Marketing, Vol. 48 Nos 3/4, pp. 432-452.

Cao, X., Guo, X., Vogel, D. and Zhang, X. (2016), "Exploring the influence of social media on employee work performance", Internet Research, Vol. 26 No. 2, pp. 529-545.

Carayannis, E.G., Gigoroudis, E., Del Giudice, M., Della Peruta, M.R. and Sindakis, S. (2017), "An exploration of contemporary organizational artifacts and routines in a sustainable excellence context", Journal of Knowledge Management, Vol. 21 No. 1, pp. 35-56.

Carriano, M. (2014), "Pricing myopia: do leading companies capture the full value of their pricing strategies?", Management Decision, Vol. 52 No. 1, pp. 159-178.

Chen, X.A., Wang, Z. and Yuan, H. (2017), "Optimal pricing for selling to a static multi-period newsvendor", Operations Research Letters, Vol. 45 No. 5, pp. 415-420.

Chen, Y.-C., Li, P.-C. and Lin, Y.-H. (2013), "How inter- and intra-organisational coordination affect product development performance: the role of slack resources", Iournal of Business \& Industrial Marketing, Vol. 28 No. 2, pp. 125-136.

Chowdhury, M.H. and Quaddus, M. (2017), "Supply chain resilience: conceptualization and scale development using dynamic capability theory", International Journal Production Economics, Vol. 188, pp. 185-204.

Cordero-Gutiérrez, R. and Santos-Requejo, L. (2016), "Intention to participate in online commercial experiments by social network's users: differences in gender and age", Management Research Review, Vol. 39 No. 4, pp. 378-398.

Cvtanovic, S., Despotovic, D. and Filipovic, M. (2015), "The concept of social Capital in economic theory", Ekonomika, Vol. 61 No. 1, pp. 73-84.

Del Giudice, M. and Maggioni, V. (2014), "Managerial practices and operative directions of knowledge management within inter-firm networks: a global view", Journal of Knowledge Management, Vol. 18 No. 5, pp. 841-846.

Del Giudice, M., Della Peruta, M. and Carayanis, E. (2013), Social Media and Emerging Economies: Technological, Cultural and Economic Implications, Springer Science and Business Media.

Dijkstra, T.K. and Henseler, J. (2015), "Consistent and asymptotically normal PLS estimators for linear structural equations", Computational Statistics \& Data Analysis, Vol. 81 No. 1, pp. 10-23.

Dinda, S. (2014), "Inclusive growth through creation of human and social Capital", International Iournal of Social Economics, Vol. 41 No. 10, pp. 878-895.

Dodd, M.D. (2016), "Intangible resource management: social Capital theory development for public relations", Journal of Communication Management, Vol. 20 No. 4, pp. 289-311.

Dolfsma, W. and van der Eijk, R. (2017), "Network position and firm performance - the mediating role of innovation", Technology Analvsis \& Strategic Management, Vol. 29 No. 6, pp. 556-568.

Duffy, M., Scott, K., Shaw, J., Tepper, B. and Aquino, K. (2012), "A social context model of envy and social undermining”, Academv of Management Iournal, Vol. 55 No. 3, pp. 643-666. 
Duta, S., Zbaracki, M.J. and Bergen, M. (2003), "Pricing process as a capability: a resource-based perspective”, Strategic Management Iournal, Vol. 24 No. 7, pp. 615-630.

Fernandes, R., Pinho, C. and Gouveia, B. (2015), "Supply chain networks design and transfer-pricing", The International Journal of Logistic Management, Vol. 26 No. 1, pp. 128-146.

Ferraris, A., Santoro, G. and Dezi, L. (2017), "How MNC's subsidiaries may improve their innovative performance? The role of external sources and knowledge management capabilities", Lournal of Knowledge Management, Vol. 21 No. 3, pp. 540-552.

Foroudi, P., Gupta, S., Nazarian, A. and Duda, M. (2017), "Digital technology and marketing management capability: achieving growth in SMEs", Qualitative Market Research: An International Journal, Vol. 20 No. 2, pp. 230-246.

Gao, H., Ren, M., Zhang, J. and Sun, R. (2016), "Network gatekeeping in SME exporters' market entry in China", International Marketing Review, Vol. 33 No. 2, pp. 276-297.

Guenzi, P., De Luca, L.M. and Spiro, R. (2016), “The combined effect of customer perceptions about a salesperson's adaptive selling and selling orientation on customer trust in the salesperson: a contingency perspective", Journal of Business \& Industrial Marketing, Vol. 31 No. 4, pp. 553-564.

Guercini, S., La Rocca, A., Runfola, A. and Snehota, I. (2014), "Interaction behaviors in business relationships and heuristics: issues for management and research agenda", Industrial Marketing Management, Vol. 43 No. 6, pp. 929-937.

Hartmann, A. and Caerteling, J. (2010), "Subcontractor procurement in construction: the interplay of price and trust”, Supply Chain Management: An International Journal, Vol. 15 No. 5, pp. 347-353.

Henseler, J., Dijkstra, T.K., Sarstedt, M., Ringle, C.M., Diamantopoulous, A., Straub, D.W., Ketchen, D.J., Jr, Hair, J.F., Hult, G.T.M. and Calantone, R.J. (2013), "Common beliefs and reality about partial least squares: comments on Rönkkö \& Evermann”, Organizational Research Methods, Vol. 17 No. 2, pp. 182-209.

Hofer, K.M., Niehoff, L.M. and Wuehrer, G. (2015), "The effects of dynamic capabilities on value-based pricing and export performance”, in Zou, S., Xu, H. \& Shi, L.H. (Eds), Entrepreneurship in International Marketing (Advances in International Marketing, Volume 25), Emerald Group Publishing Limited, London.

Holden, J. (2016), "Elevating the sales profession: what sellers crave and sales managers need for success", Industrial and Commercial Training, Vol. 48 No. 4, pp. 194-198.

Hu, L. and Bentler, P.M. (1998), "Fit indices in covariance structure modeling: sensitivity to underparameterized model misspecification”, Psvchological Methods, Vol. 3 No. 4, pp. 424-453.

IBM (2016), The State of Social Media Analytics White Papers, IBM Research, Austin, Texas.

Ingenbleek, P.T. and van ders Lans, I. (2013), "Relating price strategies and price-setting practices", European Journal of Marketing, Vol. 47 Nos 1/2, pp. 27-48.

Ishfaq, R., Raja, U. and Rao, S. (2016), "Seller-induced scarcity and price-leadership impact on product returns in the internet retail supply chain", The International Iournal of Logistics Management, Vol. 27 No. 2, pp. 552-569.

Jaakkola, M., Frösen, J. and Tikkanen, H. (2015), "Various forms of value-based selling capabilitycommentary on "value-based selling: an organizational capability perspective", Industrial Marketing Management, Vol. 45 No. 2, pp. 113-114.

Jarvenpaa, S.L. and Majchrzak, A. (2016), "Interactive self-regulation theory for sharing and protecting in interorganizational collaborations", Academy of Management Review, Vol. 41 No. 1, pp. 9-27.

Kamboj, S. and Rahman, Z. (2015), "Marketing capabilities and firm performance: literature review and future research agenda", International Journal of Productivity and Performance Management, Vol. 64 No. 8, pp. 1041-1067.

Kim, Y.-M., Newby-Bennett, D. and Song, H.-J. (2012), "Knowledge sharing and institutionalism in the healthcare industry”, Journal of Knowledge Management, Vol. 16 No. 3, pp. 480-494. 
Kluge, P.N. and Fassnacht, M. (2015), "Selling luxury goods online: effects of online accessibility and price display”, International Iournal of Retail \& Distribution Management, Vol. 43 Nos 10/11, pp. 1065-1083.

Kocas, C., Pauwels, K. and Bohlmann, J.D. (2018), "Pricing best sellers and traffic generators: the role of asymmetric cross-selling”, Journal of Interactive Marketing, Vol. 41, pp. 28-43.

Konuk, F.A. (2015), "The effects of price consciousness and sale proneness on purchase intention towards expiration date-based priced perishable foods", British Food Iournal, Vol. 117 No. 2, pp. $798-804$.

Kozienkova, I., Palmatier, R.W., Fang, E., Xiao, B. and Huang, M. (2017), "Online relationship formation", Journal of Marketing, Vol. 81 No. 3, pp. 21-40.

Kregar, T. and Antoncic, B. (2016), "The relationship between the entrepreneur's personal network multiplexity and firm growth”, The Economic Research-Ekonomska Istrazivania, Vol. 29 No. 1, pp. 1126-1135.

Kucharska, W. and Wright, L.T. (2017), "Consumer social network Brand identification and personal branding. How do social network users choose among Brand sites?", Cogent Business \& Management, Vol. 4 No. 1.

Kwon, S.W. and Adler, P. (2014), "Social Capital: maturation of a field of research", Academv of Management Review, Vol. 39 No. 4, pp. 412-422.

Lado, A., Boyd, N., Wright, P. and Kroll, M. (2006), "Paradox and theorizing within the resource-based view”, Academy of Management Review, Vol. 31 No. 1, pp. 115-131.

Lee, S., Illia, A. and Lawson-Body, A. (2011), "Perceived price fairness of dynamic pricing", Industrial Management \& Data, Vol. 111 No. 4, pp. 531-550.

Li, X., Ren, X. and Zheng, X. (2015), "Management of competition among sellers and its performance implications for business-to-business electronic platforms Dynamic analysis by VAR model", Nankai Business Review, Vol. 6 No. 2, pp. 199-222.

Lii, Y.-S. and Lee, M. (2012), "The joint effects of compensation frames and price levels on service recovery of online pricing error", Managing Service Quality, Vol. 22 No. 1, pp. 4-20.

Liozu, S.M. and Hinterhuber, A. (2013), "Pricing orientation, pricing capabilities, and firm performance", Management Decision, Vol. 51 No. 3, pp. 594-614.

Marin, A., Mitchell, R. and Lee, J. (2015), "The vulnerability and strength duality in ethnic business: a model of stakeholder salience and social Capital", Lournal of Business Ethics, Vol. 130 No. 2, pp. 271-289.

Morgan, N.A., Vorhies, D.W. and Mason, C.H. (2009), "Market orientation, marketing capabilities, and firm performance", Strategic Management Journal, Vol. 30 No. 8, pp. 909-920.

Ngai, E.W., Tao, S.S. and Moon, K.K. (2015), "Social media research: theories, constructs, and conceptual frameworks", International Journal of Information Management, Vol. 35 No. 1, pp. 33-44.

Niazi, A. and Hassan, H. (2016), "Trust and economic performance evidence from cross-country panel data analysis", Review of International Business, Vol. 26 No. 3, pp. 371-391.

Nitzl, C., Roldan, J.L. and Cepeda, G. (2016), "Mediation analysis in partial least squares path modeling: helping researchers discuss more sophisticated models", Industrial Management \& Data Sustems, Vol. 116 No. 9, pp. 1849-1864.

Oldroyd, J.B. and Morris, S.S. (2012), "Catching falling stars: a human resource response to social capital's detrimental effect of information overload on star employees", Academv of Management Review, Vol. 37 No. 3, pp. 396-418.

Panagopoulos, N.G., Rapp, A.A. and Ogilvie, J.L. (2017), "Salesperson solution involvement and sales performance: the contingent role of supplier firm and customer-supplier relationship characteristics", Journal of Marketing, Vol. 81 No. 4, pp. 144-164. 
Parra-Requena, G., Ruiz-Ortega, M. and García-Villaverde, P.M. (2012), “Towards pioneering through capabilities in dense and cohesive social networks", Iournal of Business and Industrial Marketing, Vol. 27 No. 1, pp. 41-56.

Perry-Smith, J.E. and Mannucci, P.V. (2017), "From creativity to innovation: the social network drivers of the four phases of the idea journey", Academv of Management Review, Vol. 42 No. 1, pp. 53-79.

From social network to firm

performance

Pinto, L.H. and Araújo, R.C. (2016), "Social networks of Portuguese self-initiated expatriates", Lournal of Management Development, Vol. 35 No. 1, pp. 89-103.

Poon, P., Albaum, G. and Yin, C.-Y. (2017), "Exploring risks, advantages and interpersonal trust in buyer-salesperson relationships in direct selling in a non-Western country", International Journal of Retail \& Distribution Management, Vol. 45 No. 3, pp. 328-342.

Pratono, A.H. (2016), "Strategic orientation and information technological turbulence", Business Process Management Iournal, Vol. 22 No. 2, pp. 1-15.

Pratono, A.H. and Mahmood, R. (2015), "Mediating effect of marketing capability and reward philosophy in the relationship between entrepreneurial orientation and firm performance", Journal of Global Entrepreneurship Research, Vol. 5 No. 1, pp. 1-12.

Putnam, R. (2000), Bowling Alone, Simon \& Schuster Paperbacks, New York, NY.

Qiu, C. and Leszczyc, P.P. (2016), "Send-for-review decisions, Brand equity, and pricing", European Iournal of Marketing, Vol. 50 Nos 1/2, pp. 145-165.

Rathi, D. and Given, L.M. (2017), 'Non-profit organizations' use of tools and technologies for knowledge management: a comparative study", Journal of Knowledge Management, Vol. 21 No. 4, pp. 718-740.

Rouziés, D. and Hulland, J. (2014), "Does marketing and sales integration always pay off? Evidence from a social Capital perspective", Journal of Academv of Marketing Science, Vol. 42 No. 5, pp. 511-527.

Salam, M.A. (2017), "The mediating role of supply chain collaboration on the relationship between technology, trust and operational performance", Benchmarking: An International Journal, Vol. 24 No. 2, pp. 298-317.

Santoro, G., Vrontis, D., Thrassou, A. and Dezi, L. (2017), "The Internet of Things: building a knowledge management system for open innovation and knowledge management capacity", Technological Forecasting \& Social Change, Vol. 116 No. 1, pp. 1-8.

Schilke, O. (2014), "On the contingent value of dynamic capabilities for competitive advantage: the nonlinear moderating effect of environmental dynamism", Strategic Management Iournal, Vol. 35 No. 2, pp. 179-203.

Scuotto, V., Del Giudice, M., Bresciani, S. and Meissner, D. (2017), "Knowledge-driven preferences in informal inbound open innovation modes. An explorative view on small to medium enterprises", Journal of Knowledge Management, Vol. 21 No. 3, pp. 640-655.

Scuotto, V., Del Giudiece, M., della Peruta, M.R. and Tarba, S. (2017), "The performance implications of leveraging internal innovation through social media networks: an empirical verification of the smart fashion industry", Technological Forecasting and Social Change, Vol. 120 No. 7, pp. 184-194.

Scuotto, V., Santoro, G., Bresciani, S. and Del Giudice, M. (2017), "Shifting intra- and interorganizational innovation processes towards digital business: an empirical analysis of SMEs", Creativity and Innovation Management, Vol. 26 No. 3, pp. 247-255.

Shin, S.R., Han, J., Marhold, K. and Kang, J. (2017), "Reconfiguring the firm's core technological portfolio through open innovation: focusing on technological M\&a", Journal of Knowledge Management, Vol. 21 No. 3, pp. 571-591.

Singh, R., Kumar, N. and Puri, S. (2017), "Thought self-leadership strategies and sales performance: integrating selling skills and adaptive selling behavior as missing links", Lournal of Business \& Industrial Marketing, Vol. 32 No. 5, pp. 652-663. 
Tang, T.P., Fu, X. and Xie, Q. (2017), "Influence of functional conflicts on marketing capability in channel relationships", Journal of Business Research, Vol. 78, pp. 252-260.

Terpend, R. and Ashenbaum, B. (2012), "The intersection of power, trust, and supplier network size: implication for supplier performance", Lournal of Subplv Chain Management, Vol. 48 No. 3, pp. 52-77.

Tian, X. (2016), "Network domains in social networking sites: expectations, meanings, and social Capital", Information. Communication \& Societv, Vol. 19 No. 2, pp. 188-202.

Tilmes, K. (2015), "To meet the jobs challenge, maximize the impact of SMEs".

Tubadji, A. (2014), "Was weber right? The cultural Capital root of socio-economic growth examined in five European countries", International Journal of Mantower, Vol. 35 Nos 1/2, pp. 56-88.

van der Rest, J.-P., Roper, A. and Wang, X.L. (2018), "Why is a change of company pricing so hard to implement?", International Iournal of Hospitality Management, Vol. 69, pp. 30-40.

Wang, Y. (2016), "Investigating dynamic capabilities of family businesses in China: a social Capital perspective", Journal of Small Business and Enterprise Development, Vol. 23 No. 4, pp. 1057-1080.

Wang, Y. and Byrd, T.A. (2017), "Business analytics-enabled decision-making effectiveness through knowledge absorptive capacity in health care", Lournal of Knowledge Management, Vol. 21 No. 3, pp. 517-539.

Wetzel, H.A., Hammerschmidt, M. and Zablah, A.R. (2014), "Gratitude versus entitlement: a dual process model of the profitability implication of customer prioritization”, Lournal of Marketing, Vol. 78 No. 3, pp. 1-19.

Wu, J.-J., Chen, Y.-H., Chien, S.-H. and Wu, W.-K. (2016), "Attachment relationship study of trust and trust transfer", Journal of Service Theory and Practice, Vol. 26 No. 5.

Xu, X., Nguyen, B. and Chen, Y. (2016), "Internet of things capability and alliance entrepreneurial orientation, market orientation and product and process innovation", Internet Research, Vol. 26 No. 2, pp. 402-434.

Yang, J., Alejandro, T.B. and Boles, J. (2011), “The role of social Capital and knowledge transfer in selling center performance", Lournal of Business \& Industrial Marketing, Vol. 26 No. 3, pp. 152-161.

Zhang, J.Z., Watson IV, G.F., Palmatier, R.W. and Dant, R.P. (2016), “Dynamic relationship marketing”, Journal of Marketing, Vol. 80 No. 5, pp. 53-75.

\section{Further reading}

Jonsson, S. and Lindbergh, J. (2013), "The development of social Capital and financing of entrepreneurial firms: from financial bootstrapping to bank funding", Entrebreneurshit Theorv and Practice, Vol. 37 No. 4, pp. 661-686.

Lockett, A., Currie, G., Finn, R., Martin, G. and Waring, J. (2014), "The influence of social position on sensemaking about organizational change", Academy of Management Review, Vol. 57 No. 4, pp. 1102-1129.

Pillai, K.G., Hodgkinson, G.P., Kalyanaram, G. and Nair, S. (2017), "The negative effects of social Capital in organizations: a review and extension", International Journal of Management Reviews, Vol. 19 No. 1, pp. 97-124.

Pratono, A.H., Saputra, R. and Pudjibudojo, J.K. (2016), "The social Capital and firm performance: evident from Indonesia small businesses", International Journal of Economics and Financial Issues, Vol. 6 No. S7, pp. 47-50.

Yang, C. and Liu, H.-M. (2012), "Boosting firm performance via enterprise agility and network structure", Management Decision, Vol. 50 No. 6, pp. 1022-1044. 



Product Information:-
Journals
eJournals
Backfiles
Publish in a journal

Books

Case Studies

Open Access

Regional information

\section{Services}

Publishing Services

\section{Resources:}

Licensing Solutions

For Authors

For Editors

For Reviewers

For Librarians

Research Zone

Student Zone

Teaching Zone

\#RealWorldResearch

Real World Impact

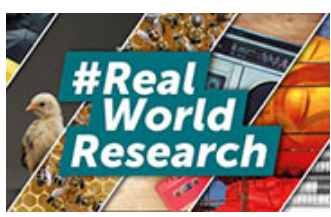

\section{Need help with your manuscript?}

emerald

AUTHOR SERVICES
Home > Emerald journals > Management Research Review - Editorial team

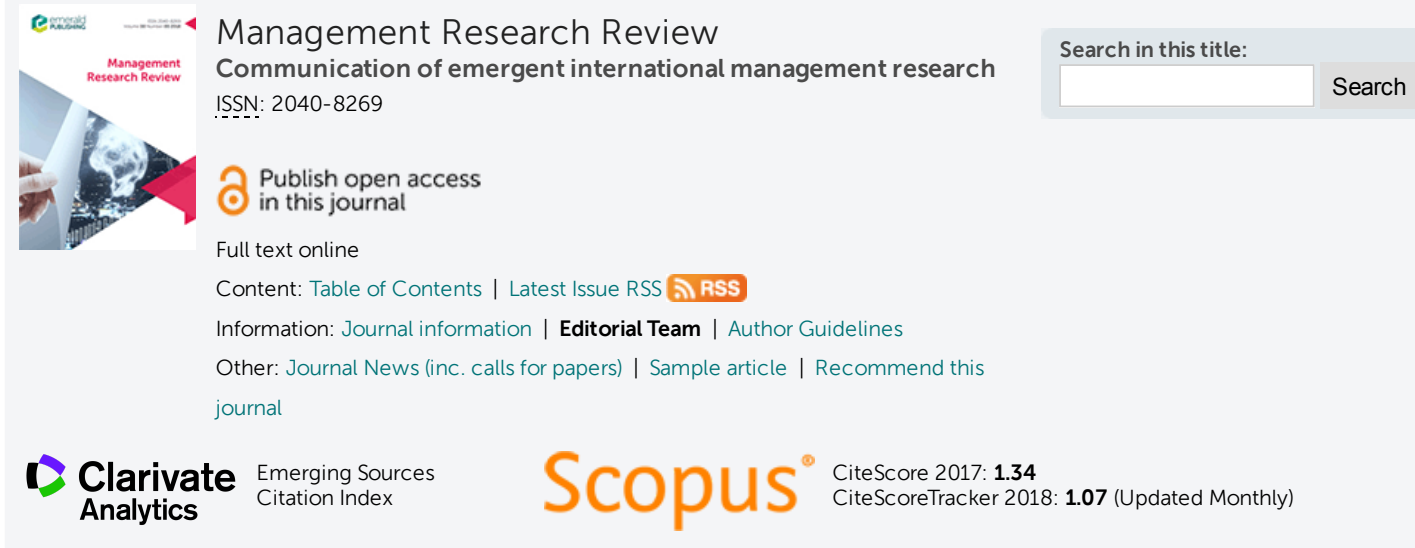

\section{Editorial team}

\section{Co-Editors}

\section{Lerong $\mathrm{He}$}

Chair, Department of Business Administration, State University of New York at Brockport, USA

theabrockport.edu

Jay J. Janney

Chair, Department of Management and Marketing, University of Dayton, USA

jjanney1@udayton.edu

\section{Publisher}

Patti Davis

pdavis@emeraldgroup.com

\section{Content Editor}

Aisha Mayet

amayet@emeraldgroup.com

\section{Editorial Advisory Board}

Steven H. Appelbaum, John Molson School of Business, Concordia University, Canada

Timothy Bartram, School of Business, La Trobe University, Australia

Michael Boniface, California State University, Sacramento, USA

Gary Chaison, Graduate School of Management, Clark University, USA

Stewart Clegg, University of Technology Sydney, Australia

James J Cordeiro, Department of Business Administration \& Economics, SUNY at Brockport, USA

Alison Dean, Newcastle Business School, Australia

Behnam Fahimnia, University of Sydney, Australia

Marianne Gloet, University of Melbourne, Australia

Faizul Huq, College of Business, Ohio University, USA

Peter Jones, University of Gloucestershire Business School, UK

Boris Kabanoff, School of Management, Queensland University of Technology, Australia

Anastasia Katou, University of Macedonia, Greece

Marios I. Katsioloudes, Qatar University, Qatar

Lisa A Keister, Duke University, USA

Sascha Kraus, University of Liechtenstein, Liechtenstein

Darren Lee-Ross, James Cook University, Australia

Frank Lefley, University of Hradec Králové, Czech Republic

Laura Meade, M J Neeley School of Business, Texas Christian University, USA

R D Pathak, School of Social \& Economic Development, The University of South Pacific, Fiji

Ken Peattie, Cardiff University, UK

Rajesh K. Pillania, Management Development Institute, Gurgaon, India

Adrien Presley, Division of Business and Accountancy, Truman State University, USA

Abdul A. Rasheed, University of Texas at Arlington, USA

Elena Revilla, Instituto de Empresa, Spain

Hazel Rosin, York University, Canada

Joseph Sarkis, Worcester Polytechnic Institute, USA

Tara Shankar Shaw, Indian Institute of Technology, Bombay, India 
Clive Smallman, University of Western Sydney, Australia

Karen Spens, Hanken School of Economics, Finland

R P Sundarraj, Indian Institute of Technology Madras, India

Srinivas Talluri, Eli Broad Graduate School of Management, Michigan State University, USA

Vas Taras, University of North Carolina at Greensboro, USA

Greg Teal, School of Management, University of Western Sydney, Australia

Diego Vazquez-Brust, University of Portsmouth, Portsmouth Business School, UK

Karen Yuan Wang, School of Management, University of Technology, Sydney, Australia

Cherrie Jiuhua Zhu, Monash University, Australia

\section{About Emerald}

About us
Company information
Working for Emerald
Contact us
How to find us

Policies \& Information

Company policy repository

End user terms

Digital preservation

Standards of conduct (contractors)

Supplier code of conduct

Modern Slavery Act transparency statement

Gender Pay Gap report

\section{Emerald Websites}

Emerald Insight

Emerald Group

50th Anniversary

Emerald Bookstore

Emerald Careers

The Emerald Foundation

(C) Copyright 2018 Emerald Publishing Limited

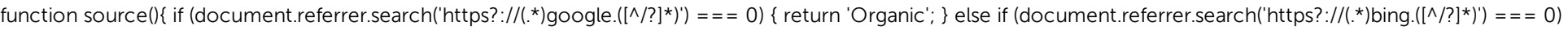

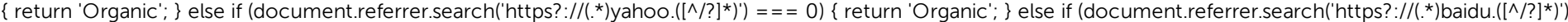

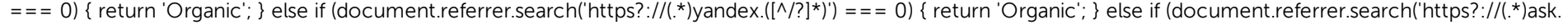
$\left.\left.\left([\wedge / ?]^{\star}\right)^{\prime}\right)===0\right)$ \{ return 'Organic'; $\}$ else if (document.referrer.search('https?://(*)naver. $\left.\left.\left([\wedge / ?]^{\star}\right)^{\prime}\right)===0\right)\{$ return 'Organic'; $\}$ 


\section{eemeraldinsight}

Log in Register Help Cart Admin Blog

$$
\begin{array}{ll}
\text { Previous Issue } \quad \text { Next Issue > }
\end{array}
$$

\section{Table Of Contents: Volume 41 Issue 6}

Published: 2018, Start page: 626

Special Issue: Collaborative firms, networks and social media: implications for management research and practice

Editor(s): Manlio Del Giudice, Elvira Anna Graziano and Veronica Scuotto

Icon key: You have access to this item BBackfile GEarlycite A Abstract only $\partial$ Open access

Select all Add to Marked List | Track Citations | Email to a Friend | Send to Citation Mgr

$\square$ Exploring antecedents of social media usage in B2B: a systematic review

Federica Pascucci, Chiara Ancillai, Silvio Cardinali (pp. 629 - 656)

Keywords: Social networks, B2B, Social media adoption, Business-tobusiness, Systematic literature review, Other management related topics, Social media usage

Type: Literature review

Abstract | HTML | PDF (379 KB) | Reprints and Permissions

- Social media marketing in luxury brands: A systematic literature review and implications for management research

Elisa Arrigo (pp. 657 - 679)

Keywords: Systematic review, Co-creation, Competitive advantage,

Social media marketing, Digital luxury, Luxury brand

Type: Literature review

Journal Information

ISSN: $2040-8269$

Online from: 2010

Subject Area:

Business,

Management \&

Strategy

Previously published as: Management

Research News

Current Issue

| Available Issues

| Earlycite

RSS ToC
Alert

1 Clarivate Analytics COPUs

Emerging Sources

Citation Index Publish ope

in this jourr

Abstract | HTML | PDF (325 KB) | Reprints and Permissions 
From social network to firm performance: The mediating effect of trust, selling capability and pricing capability Aluisius Hery Pratono (pp. 680 - 700)

Keywords: Social network, Trust, Firm performance, Social capital theory, Entrepreneurship and small business management, Pricing capability, Selling capability

Type: Research paper

Abstract | HTML | PDF (358 KB) | Reprints and Permissions

\section{Knowledge exploration and ICT knowledge} exploitation through human resource management: A study of Italian firms

Gabriele Santoro, Antonio Usai (pp. 701 - 715)

Keywords: Human resource management, ICT, HRM practices, Knowledge management, Knowledge exploitation, Knowledge exploration

Type: Research paper

Abstract | HTML | PDF (275 KB) | Reprints and Permissions

$\square$ The link between mergers and acquisitions and innovation: A systematic literature review

Luca Dezi , Enrico Battisti , Alberto Ferraris, Armando Papa (pp. 716 - 752)

Keywords: Literature review, Innovation, Intellectual capital, Open innovation, Other management-related topics, Corporate finance, M\&As, Structured literature review, Mergers and acquisitions

Type: Literature review

Abstract | HTML | PDF (630 KB) | Reprints and Permissions

$\square$ A relational perspective on pure project performance: Network centrality and cinematic achievements in the Hong Kong film industry Jimmy H.T. Chan, Anthony C.K. Ko, Alan K.M. Au, Matthew C.H. Yeung (pp. 753 - 772)

Keywords: Social network analysis, Panel data analysis, Other management-related topics, Centrality, Cinematic performance, Network resources, Pure projects Type: Research paper Abstract | HTML | PDF (368 KB) | Reprints and Permissions
The most popular papers from this title in the past 7 days:

Manage Your Time Well

Social eWOM: does it affect the brand attitude and purchase intention of brands?

Entrepreneurial orientation and firm performance: the mediating role of functional performances

Conducting research interviews

Social media marketing in luxury brands: A systematic literature review and implications for management research

See more >

Further Information

About the Journal

Sample Articles

Purchase Information

Editorial Team

Write for this journal

\section{Guest editorial}

Manlio Del Giudice, Elvira Anna Graziano, Veronica Scuotto (pp. 626 - 628) Type: Non-article

Abstract | HTML | PDF (62 KB)

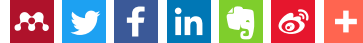

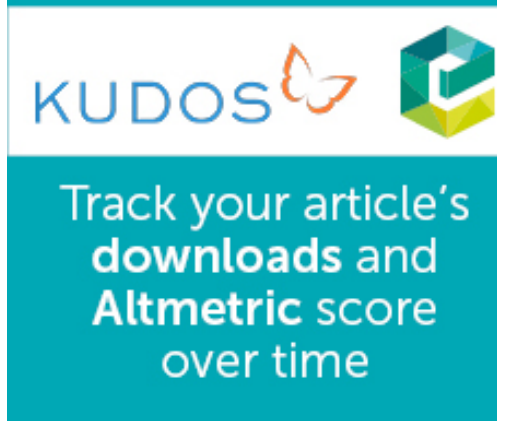




\section{About Emerald}

About Us

Company Information

Working for Emerald

Contact Us

How to Find Us

\section{Policies \& Information}

Cookie Policy

Privacy Policy

Copyright Policy

Industry Standards

End User Terms

Digital Preservation

Accessibility

Text and Data Mining Licence

Modern Slavery Act transparency

statement

\section{Emerald Websites}

Emerald Publishing

Emerald Group

50th Anniversary

Emerald Bookstore

Emerald Careers

The Emerald Foundation 


\section{e emeraldinsight}

\section{Management Research Review}

From social network to firm performance: The mediating effect of trust, selling

capability and pricing capability

Aluisius Hery Pratono,

\section{Article information:}

To cite this document:

Aluisius Hery Pratono, (2018) "From social network to firm performance: The mediating effect of trust, selling capability and pricing capability", Management Research Review, https://doi.org/10.1108/

MRR-03-2017-0080

Permanent link to this document:

https://doi.org/10.1108/MRR-03-2017-0080

Downloaded on: 10 April 2018, At: 15:10 (PT)

References: this document contains references to 106 other documents.

To copy this document: permissions@emeraldinsight.com

Access to this document was granted through an Emerald subscription provided by

Token: Eprints:UU2ERXP8Y9RCIYVA5TAG:

\section{For Authors}

If you would like to write for this, or any other Emerald publication, then please use our Emerald for Authors service information about how to choose which publication to write for and submission guidelines are available for all. Please visit www. emeraldinsight. com/authors for more information.

\section{About Emerald www.emeraldinsight.com}

Emerald is a global publisher linking research and practice to the benefit of society. The company manages a portfolio of more than 290 journals and over 2,350 books and book series volumes, as well as providing an extensive range of online products and additional customer resources and services.

Emerald is both COUNTER 4 and TRANSFER compliant. The organization is a partner of the Committee on Publication Ethics (COPE) and also works with Portico and the LOCKSS initiative for digital archive preservation.

*Related content and download information correct at time of download. 